\title{
A Literature Review on the Impact of Games on Learning English Vocabulary
}

\section{to Children}

\author{
Lina Lafta Jassim \\ College of Art, University of Thi Qar, Iraq
}

Hisham Dzakiria

Associate Professor at College of language, University of Utara Malaysia, Malaysia

Corresponding Author: Lina Jassim

E-mail: 1fnar83@gmail.com

\begin{tabular}{|c|c|}
\hline $\begin{array}{l}\text { Received: } \\
\text { 22/05/2019 }\end{array}$ & $\begin{array}{l}\text { Abstract } \\
\text { Digital games play a significant role in the life of the new generation. }\end{array}$ \\
\hline $\begin{array}{l}\text { Accepted: } \\
\text { 30/06/2019 }\end{array}$ & $\begin{array}{l}\text { Although there are many criticisms, many studies focus on the importance } \\
\text { of digital games in improving learner's vocabulary in the target language. } \\
\text { Researchers have begun conducting several researches on how using } \\
\text { games in the class can foster vocabulary learning. The aim of this paper is }\end{array}$ \\
\hline $\begin{array}{l}\text { Keywords: } \\
\text { Digital Games, } \\
\text { Effects, Benefits, } \\
\text { Challenges }\end{array}$ & $\begin{array}{l}\text { to investigate the impacts of digital games on children's vocabulary } \\
\text { learning depending on a literature review. Many studies focus on the } \\
\text { impacts of digital games on different aspects of education. This conceptual } \\
\text { paper aims to shed light on some games' benefits, and challenges which } \\
\text { educators and children face in the use of digital games. The findings of this } \\
\text { paper show that Games are used not only for making children successful in } \\
\text { EFL classes but more importantly, for motivating them and increasing the } \\
\text { cooperation among children. In addition, the findings state that there are } \\
\text { advantages as well as disadvantages in using games for learning English } \\
\text { vocabulary. }\end{array}$ \\
\hline
\end{tabular}

\section{INTRODUCTION}

Nowadays, there is an increasing interest towards using technology in different fields of human life, particularly, in education. Digital games are used for entertainment and facilitating the process of learning (Ilomaki \& Kankaanranta, 2009). In addition, the use of technology has a significant effect in various social and cultural contexts, as it helps in improving the language of children as well as increasing their cultural awareness. According to Taghizadeh et al. (2017), the use of games enables children to learn vocabulary better than using traditional ways. It is necessary to understand two important facts before using a game as an educational tool: children competence and their cultural feedback must be taken into account. In addition, it should be useful for children with lower language ability and should be easily practiced anywhere. Many experienced course book and procedural manual scholars have stressed that games have a great learning value (Derakhshan \& Khatir, 2015). This paper offers the rationale for implementing games as a stress-free tool of learning words. It is believed that games can have the potentiality to contextualize learning words.

\section{THE LITERATURE REVIEW}

There are several scholars indicate the effect of using games in learning the vocabulary of the target language (Vasileiadou \& Makrina, 2017). Similarly, Ashraf, et al. (2014) addressed the effect of using games in learning the vocabulary for children. For those scholars, participants are divided into two groups. One of these group was taught vocabulary of the target language by using games. Twenty-five was the number of that group. However, 
the others, the other group of fifteen children, were taught new vocabulary by using traditional ways (their course books). Their achievements showed that the effective use of games in learning vocabulary (Ashraf et al., 2014). Also, Calvo-Ferrer (2017) investigated the game impact in learning of vocabulary. In his study, the number of participants who were exposed to the vocabulary of the foreign language during using games while the other numbers learned the foreign vocabulary by practicing vocabulary exercises in their textbooks. Their results in pre and post-tests showed that the outcomes of the participants who were taught vocabulary with using games in the short period were better than those who learned vocabulary by using traditional means. In addition, using games was more attractive for children and motivated them to improve their English vocabulary.

Peterson (2013) studied the impact of learning vocabulary during games in kindergarten in the Netherlands. In his study, participants were 164, which remained fifteen weeks. Peterson conducted his experience on sixty-seven children. Those children played games for fifteen minutes two times a week. However, ninety-seven children were taught by practicing the regular curriculum. His findings indicated a positive impact of computer games in the acquisition of vocabulary. Similarly, Saffarian and Gorjian (2012) indicated the same results in their study. Participants were 418 teachers of English, as well as 111 children .Some of the children in that study were taught using computer games in classes while the other children were taught using regular activities. The data of Saffarian and Gorjian's research indicated an important difference in the children's performance ( i.e., children with games-based learning were better than the others). Besides, Sundqvist and Sylvèn (2014) emphasized the significant role of games in increasing of the children's motivation to learn the vocabulary of the English language. Seventy-six EL children in the research of Sundqvist and Sylvèn were in the fourth stage of primary school. According to the study results, most of the children were more confident and motivated to learn English vocabulary as well as bring a fun element to the children's class. Moreover, Derakhshan and Khatir (2015) proposed that using games leads to get better outcomes in learning new vocabulary than using traditional strategies. Conversely, Bytheway's research (2014) investigated the role of online games on using vocabulary for children in learning processes. Her study includes six professional players. Her findings have reflected that using of games help the children in learning vocabulary in meaningful contexts. So, the process of learning is more affected and successful. Jensen (2017) showed the important role of games in developing the acquisition of English vocabulary. Finally, Yudintseva (2015) used mixed methods to reflect that learning with using games can help EFL children in enhancing their vocabulary in a target language context. All the researchers come to a conclusion that vocabulary in a target language is developed by engaging children in playing various games. In Iran, Vahdat and Behbahani (2013) showed that using games has a significant impact in learning vocabulary for EFL children. The children who participated in that research were forty at intermediate stage. Vahdat and Behbahani asked their participants to conduct TOEFL test. According to the study results, the participants who practiced games in their vocabulary learning got better achievements than others, and it was indicated that males were more motivated towards using video-game in their learning of vocabulary than females. So, they concluded that gender and learning vocabulary via games were interrelated. In addition, they emphasized that digital games provide children with a meaningful context that enables them to discuss and facilitate their comprehension of other objects and can improve their English abilities as well as increase their vocabulary. It is necessary for children to pay attention to certain aspects of English language including vocabulary. Therefore, children should know the English vocabulary to master English skills. Vocabulary is significant in supporting children skills (Bakhsh, 2016). To be able to speak and write the English language, thousands oxfords dictionaries are necessary to be learned (Peterson, 2013). There is a close relationship between vocabulary 
and four English skills (Tuan, 2011). Children can practice all English skills well if they learn vocabulary and comprehend its link with all skills of English (Schmitt, 2010). However, learning vocabulary is the main challenge for learning a target language; most children sound to face the same problems in learning vocabularies because of a lack of motivation (Jung \& Graf, 2008). There are several ways and strategies that can be used by teachers to enable children to learn vocabulary. The use of real materials can help children to learn a lot of vocabulary. So, it is good to learn vocabulary. The direct approach is also useful where no translation for children's native language is available. Only the English language is used in the classroom. Using games with various activities is also a good method to assist children learn a lot of vocabularies in a short period.

\subsection{DEFINITION OF DIGITAL GAMES}

Games can be defined as an educational technique related to learning. For Liu and Chen (2013), a digital game can help EFL children learn vocabulary by providing them with animated graphics and impacts of audio and a good motivation to learn a foreign language vocabulary. Noraddin and Kian (2014) classified digital games into two main types: The first kind is instructional games. Educators use this kind to achieve certain educational goals with fun elements. Doing exercises can help the players of these games to learn a foreign language vocabulary (Noraddin \& Kian, 2014). Serious games are one of instructional games (Connolly at al., 2012 and Guerrero, 2011). Preschool children or children use instructional games to help them in memorizing vocabulary (Noraddin \& Kian, 2014). However, Noraddin and Kian ( 2014) stressed that all children from different ages can use serious games during teaching and preparation. The second kind of games is commercial-off-the shelf. Connolly and et al. ( 2012) showed that educators or teachers use these games without any instructional considerations or objectives. These games are used for the fun element only. However, other scholars indicated that all games (COTS) can be used to achieve instructional and entertainment goals (Ellaway, 2016).

\subsection{BENEFITS OF DIGITAL GAMES}

Many studies have emphasized that games have positive impacts on learning vocabulary, especially on children (Prensky, 2003; Leemkuil, 2006; Gee, 2012; Tüzün et al. 2009; Van Eck, 2006). Digital games provide an actual learning environment in which students collaborate with each other (Derakhshan \& Davoodi Khatir, 2015). Huyen and Nga (2003) emphasized the role of games by giving children a chance to apply English in a real communicative context in their class. Similarly, Kalaycioglu (2011) stressed the importance of digital games, as these games make the students the centre of activities in the class. That is why games can be altered in line with children's instructional goals, their age as well as their level. Providing multimedia contexts is available with using games so that children are engaged in learning vocabulary. Thus, they are encouraged to interact with other classmates and acquire vocabulary (Segal-Drori et al., 2010; Silsüpür, 2017). There are other benefits of games in different instructional aspects (Tsai et al., 2011). Digital games help young learners to learn vocabulary with more motivation than traditional teaching ways (Tuzun, et al., 2009). Furthermore, Tsai et al. (2011) asserted that using a digital game can develop learners' verbal capabilities and social skills. Similarly, many researchers stressed that technology provides children with a chance to learn four English skills not only within the class but also outside it by social interact (Gee, 2005; Wang et al, 2008). Children can develop their English by using these games in social contexts. The use of games in the classroom gives children equal chances to engage in the different activities. Particularly, the students, who have shyness and weakness in the English language can be converted into active elements in their participation and interaction by using games (Taghizadeh,2017). Digital games work as suitable means for learning vocabulary as it provides a meaningful context for learning vocabulary as well as 
adds entertainment to the classroom. According to Pomerantz and Bell (2007), using a digital game, for example, provides a fun element as well as has a significant role in the learning process for children (Taghizadeh et al., 2017). Furthermore, it can create a suitable learning environment for children making them the centre of the activities in the class (Uzun, 2009; Liu et al., 2011; Sánchez \& Olivares, 2011; Gunawardhana \& Palaniappan, 2015). For Tsai (2012), games can also enable children to overcome their learning problems and increase their motivation and confidence. The use of games can also encourage children to collaborate with other classmates in the class (Sánchez \& Olivares, 2011). Using games in education makes the feeling of fear and anxiety diminish. Digital games can promote positive impacts on children. Therefore, the scholars and teachers pay attention towards integration of games in the English teaching process. According to Mahali et al. (2016), they might consider digital games as an influential innovative means to enhance children's English learning in the knowledge age. Nowadays, scholars and teachers have recognized the use of games as it helps in facilitating the English language learning. So, they have started investigating the better ways to integrate games into classroom. They assess the use of games in activities related to different subjects and lessons. Teachers can use digital games in many educational aspects including children's motivating and offering supplementary and efficient tools (Hamizul \& Rahimi, 2015).

\subsection{CHALLENGES IN THE USE OF DIGITAL GAMES}

Some researchers suggest that there is a big challenge in the use of games in the instructional process (Koh et al., 2011; Rice, 2007; Baek, 2008). Although many Arabic instructional institutions encouraged using games in instruction, no specific strategies were done relating to the use of games. This has been resulted by the inadequate educational game equipment, teachers poor training as well as poor governmental support for technology use ( Koh et al., 2011). Other challenges are inadequate time, poor curriculum and a high cost of games (Moncada \& Moncada, 2014; Rastegarpour and Marashi (2012); Koh et al., 2011; Rice, 2007; Baek, 2008). Gunawardhana and Palaniappan (2015) indicated that physical diseases may occur with playing these games continuously. According to Taghizadeh (2017), children can suffer from addiction as a result of using games. Thus, the negative impacts can occur when they play games for a long time.

\section{CONCLUSION}

This paper focuses on the positive as well as negative impacts of using digital games in the vocabulary learning process for children. Although there are negative aspects of digital games, these games have benefits in learners' learning process, especially, when they are used in wrong way. By reviewing the literature, this study has proposed that teachers must pay attention to the time and materials during designing or select the game. Though games have also disadvantages on the vocabulary learning process, using them can help children to acquire their lesson with entertainment. In using games, children are able to remember all the vocabulary without difficulty. Games are used not only for making children successful in EFL classes but more importantly, for motivating them and increasing the cooperation among them.

\section{References}

Ashraf, H., Motlagh, F. G., \& Salami, M. (2014). The impact of online games on learning English vocabulary by Iranian (low-intermediate) EFL children. Procedia-Social and Behavioural Sciences, 98, 286-291. https://doi.org/10.1016/j.sbspro.2014.03.418

Bakhsh, S. A. (2016). Using games as a tool in teaching vocabulary to young children. English Language Teaching, 9(7), 120. 
Baek, Y. K. (2008). What hinders teachers in using computer and video games in the classroom? Exploring factors inhibiting the uptake of computer and video games. Cyber Psychology and Behavior, 6, 665-671.

Bytheway J. (2014). In-game culture affects children' use of vocabulary learning strategies in massively multiplayer online role-playing games. Int. J. Comput. Assist. Lang. Learn. Teach, 4, 1-13. https://doi.org/10.4018/ijcallt.2014100101

Galvis Guerrero, H. A. (2011). Using video game-based instruction in an EFL program: Understanding the power of video games in education. Colombian Applied Linguistics Journal, 13(1), 58-74.

Calvo-Ferrer, J. R. (2017). Educational games as stand-alone learning tools and their motivational effects on L2 vocabulary acquisition and perceived learning gains. British Journal of Educational Technology, 48(2), 264-278. https://doi.org/10.1111/bjet.12387

Connolly, T. M., Boyle, E. A., MacArthur, E., Hainey, T., \& Boyle, J. M. (2012). A systematic literature review of empirical evidence on computer games and serious games. Computers \& Education, 59(2), 661-686.

Derakhshan, A., \& Khatir, E. D. (2015). The effects of using games on English vocabulary learning. Journal of Applied Linguistics and Language Research, 2(3), 39-47.

Ellaway, R. H. (2016). A conceptual framework of game-informed principles for health professions education. Advances in Simulation, 1(1), 28.

Gee, J. P. (2005). Learning by design: Good video games as learning machines. Elearning and Digital Media, 2(1), 5-16.

Gee, J. P. (2012). The old and the new in the new digital literacies. The Educational Forum. 76(4), 418-420.

Gunawardhana, L. P. D., \& Palaniappan, S. (2015). Psychology of digital games and its effects to its users. Creative Education, 6(16), 1726.

Guerrero, H. A. G. (2011). Using video games-based instructions in an EFL program: understanding the power of video games in education. Colombian Applied Linguistics Journal, 13(1), 54-70.

Hamizul, M., \& Rahimi, N. M. (2015). Design and development of Arabic online games-a conceptual paper. Procedia-Social and Behavioral Sciences, 174, 1428-1433.

Huyen, N. T. T., \& Nga, K. T. T. (2003). Learning vocabulary through games. Asian EFL Journal, 5(4), 90-105.

Ilomäki, L. \& Kankaanranta, M. (2009). The ICT competence of the young. In L. Tan Wee Hin, \& R. Subramaniam (Eds.), Handbook of research on new media literacy at the K-12 level: Issues and challenges (pp. 101-118). Hershey, USA: IGI Global.

Jensen, S. H. (2017). Gaming as an English language learning resource among young children in Denmark. CALICO Journal; San Marcos, 31(1), 1-19. http://doi.org/10.1558/cj.29519

Jung, J., \& Graf, S. (2008). An approach for personalized web-based vocabulary learning through word association games. Paper presented at the International Symposium on Applications and the Internet. Turku, Finland.

Kalaycioğlu, H. E. (2011). The effect of picture vocabulary games and gender on four yearold children's English vocabulary performance: An experimental investigation (Unpublished master's thesis). Middle East Technical University, Turkey.

Koh, E., Kin. Y. G., Wadhwa, B., \& Lim, J. (2011). Teacher perceptions of games in Singapore schools. Simulation \& Gaming, 42(4), 1-16. 
Leemkuil, H. (2006). Is it all in the game? Learner support in an educational knowledge management simulation game. (Unpublished doctoral dissertation). University of Twente, The Netherlands.

Liu, C. C., Cheng, Y. B., \& Huang, C. W. (2011). The effect of simulation games on the learning of computational problem solving. Computers \& Education, 57(3), 1907-1918.

Mahali, M., Jamaluddin, J., Din, N. M., Ahmad, M. A. N., Jabar, F. A., \& Fadzillah, N. S. M. (2016).The Effects of Digital Games on Student's Learning Experience: A Review of Literature.

Moncada, S. M., \& Moncada T. P. (2014). Gamification of learning in accounting education. Journal of Higher Education Theory and Practice, 14(3), 9-19.

Noraddin, E. M. \& Kian, N. T. (2014). Academics' attitudes toward using digital games for learning \& teaching in Malaysia. Malaysian Online Journal of Educational Technology, 2(4), 1-21.

Prensky, M. (2003). Digital game-based learning. Computers in Entertainment (CIE), 1(1), 21-21.

Peterson, M. (2013) Computer Games and Language Learning. Palgrave Macmillan, New York. http://dx.doi.org/10.1057/9781137005175

Pomerantz, A., \& Bell, N. D. (2007). Learning to play, playing to learn: FL children as multicompetent language users. Applied Linguistics, 28(4), 556-578.

Rastegarpour, H., \& Marashi, P. (2012). The effect of card games and computer games on learning of chemistry concepts. Procedia-Social and Behavioral Sciences, 31, 597-601.

Rice, J. W. (2007). New media resistance: barriers to implementation of computer video games in the classroom. Journal of Educational Multimedia and Hypermedia, 16(3), 249-261.

Saffanian, R., \& Gorjian, B. (2012). Effect of computer-based video games for vocabulary acquisition among young children: An experimental study. Journal of Comparative Literature and Culture, l(3), 44-48.

Sánchez, J., \& Olivares, R. (2011). Problem solving and collaboration using mobile serious games. Computers \& Education, 57(3), 1943-1952.

Schmitt, N. (2010). Researching vocabulary: A vocabulary research manual. Basingstoke, England: Palgrave Macmillan.

Segal-Drori, O., Korat, O., Shamir, A., \& Klein, P. S. (2010). Reading electronic and printed books with and without adult instruction: Effects on emergent reading. Reading and Writing, 23(8), 913-930.

Silsüpür, B. (2017). Does Using Language Games Affect Vocabulary Learning in EFL Classes?. Journal of Foreign Language Education and Technology, 2(1).

Sundqvist, P., \& Sylvèn, L. K. (2014). Language-related computer use: Focus on young L2 English children in Sweden. ReCALL, 26, 3-20. https://doi.org/10.1017/S0958344013000232

Taghizadeh, M., Vaezi, S., \& Ravan, M. Digital Games, Songs and Flashcards and their Effects on Vocabulary Knowledge of Iranian Preschoolers. Studies, 5(4), 156-171.

Tsai, F.-H., Yu, K.-C., \& Hsiao, H.-S. (2012). Exploring the factors influencing learning effectiveness in digital game-based learning. Educational Technology \& Society, 15(3), 240-250.

Tuan, L. T. (2011). An Empirical Research on Self-learning Vocabulary. Theory \& Practice in Language Studies, 1(12), 1688- 1695.

Tüzün, H., Yılmaz-Soylu, M., Karakuş, T., İnal, Y., \& Kızılkaya, G. (2009). The effects of computer games on primary school studentse achievement and motivation in geography learning. Computers \& Education, 52(1), 68-77. 
Vahdat, S., \& Behbahani, A. (2013). The effect of video games on Iranian EFL children' vocabulary learning. The Reading Matrix, 13(1), 61-71.

Van Eck, R. (2006). Digital game-based learning: It's not just the digital natives who are restless. EDUCAUSE review, 41(2), 1- 16.

Vasileiadou, I., \& Makrina, Z. (2017). Using Online Computer Games in the ELT Classroom: A Case Study. English Language Teaching, 10(12), 134-150.

Uzun, L. (2009). An evaluative checklist for computer games used for foreign language vocabulary learning and practice: Vocaword sample. Novitas-Royal, 3(1), 45- 59.

Wang, C. K. J., Khoo, A., Liu, W. C., \& Divaharan, S. (2008). Passion and intrinsic motivation in digital gaming. Cyber Psychology \& Behaviour, 11(1), 39- 45.

Yudintseva, A. (2015). Game-enhanced second language vocabulary acquisition strategies: A systematic review. Open Journal of Social Sciences, 3, 101-109.

https://doi.org/10.4236/jss.2015.310015 